\title{
Beta Hematin Inhibition: Evaluating the Mechanism of Action of Some Selected Antimalarial Plants
}

Oyindamola O. Abiodun ${ }^{1 *}$, Olayide M. Oladepo ${ }^{1}$

1 University of Ibadan, Department of Pharmacology \& Therapeutics, Ibadan, Nigeria.

\section{ABSTRACT}

There is paucity of information regarding the mechanism of action of medicinal plants with antimalarial activity. Thus, the mechanism of action of twenty antimalarial plants using the $\beta$-hematin inhibition assay was evaluated. Beta-hematin synthesis from bovine hemin in the presence of saturated acetate solution at a temperature of $60^{\circ} \mathrm{C}$ and $\mathrm{pH} 7.5$ was initiated with a fixed concentration of $0.69 \mathrm{mg} /$ $\mathrm{mL}$ of chloroquine or methanol extracts of the selected plants. The fifty percent inhibitory concentration ( $\mathrm{IC}_{50}$ ) of the six most active plant extracts/standard drug was determined using linear regression. Two of the plant extracts $A$. boonei and $M$. charantia $\left(\mathrm{IC}_{50}=0.09 \pm 0.03\right.$ and $\left.0.11 \pm 0.02 \mathrm{mg} / \mathrm{mL}\right)$, showed significant activity than chloroquine $(0.36 \pm 0.16 \mathrm{mg} / \mathrm{ml} . \mathrm{P}<0.05)$ a potent $\beta$-hematin inhibitor. The $\beta$-haematin colorimetric assay is a reliable assay for determining the mechanism of action of medicinal plants that utilize the pathway.

Keywords: Beta haematin, antimalarial plants, Nigerian ethnomedicine

\section{INTRODUCTION}

Malaria is a major public health problem in sub-Sahara Africa with high rate of morbidity and mortality common in children less than 5 years of age and pregnant women ${ }^{1}$. In the last five years, malaria incidence rates (new malaria cases) fell by $37 \%$ globally and by $42 \%$ in Africa. During this same period, malaria mortality rates fell by $60 \%$ globally and by $66 \%$ in the African Region ${ }^{2}$. The recent worldwide gain achieved in reducing malaria burden is threatened by emergence and spread of drug resistance to artemisinins the most effective antimalarial available today ${ }^{3-5}$. Thus, there is need to enrich the antimalarial drug discovery pipeline with new effective agents and explore the mechanism of action of promising antimalarial agents at the early stage of drug discovery. Fortunately, several unique 
pathways have been identified such as; inhibition of DNA synthesis, de novo haem biosynthesis, glycolysis and hemozoin formation that can serve as drug targets ${ }^{6-9}$. Inhibition of hemozoin formation was explored in this study. Hemozoin is an insoluble, nontoxic disposal product formed from the digestion of haemoglobin by some blood-feeding parasites. These hematophagous organisms such as Plasmodium sp., Rhodnius sp. and Schistosoma sp. digest haemoglobin and release high quantities of free haem, which rapidly oxidizes to toxic Fe(III) hematin and is further sequestered as a nontoxic crystalline hemozoin also known as $\beta$-hematin ${ }^{10-12}$. The formation of hemozoin is essential to the survival of these parasites and can be considered as an attractive target for developing drugs for the related diseases. Quinine, and its synthetic homologs chloroquine, mefloquine, and others ${ }^{13-15} \mathrm{pu}$ tatively work by blocking conversion of hematin to a non-toxic crystalline hemozoin $^{16}$. Similarly, artemisinin, another antimalarial drug of plant origin has been shown to bind to haem ${ }^{17-18}$. Effort in this report was directed towards the determination of the mechanism of action of twenty medicinal plants selected from Nigerian antimalarial compendium through the $\beta$-hematin inhibition assay.

\section{METHODOLOGY}

\section{Plants Selection, Collection and Authentication}

Twenty plants were selected through an extensive literature search of plants used for the treatment of malaria. Twenty plant species from 16 different families were collected, and identified by a plant taxonomist at Forestry Research Institute of Nigeria (FRIN), Ibadan in March 2013.

\section{Extraction of Plant Materials}

Powdered plant material (200 g) were percolated in 70\% methanol for $72 \mathrm{~h}$. Methanol extracts were filtered and concentrated under vacuum at $40^{\circ} \mathrm{C}$ using a rotary evaporator. Thereafter, the marc was further percolated in $70 \%$ methanol and processed as described above. The extraction process was repeated 2 times for exhaustive extraction of all plant materials. The yields of the methanol extracts were determined and extracts stored at $-20^{\circ} \mathrm{C}$ until needed for study.

\section{Reagents}

Bovine hemin, pyridine anhydrous 99.8\%, hydroxyethylpiperazine-N-[2-ethanesulfonic acid] (HEPES), sodium acetate, acetic acid, sodium hydroxide $(\mathrm{NaOH})$ and chloroquine diphosphate were obtained from Sigma Aldrich Co. St. Louis, U.S.A. Hydrogen chloride (HCl), methanol and dimethyl sulfoxide (DMSO).
Qualitative Determination of Inhibition of B-Haematin Synthesis of Twenty Selected Medicinal Plants

The assay was performed based on the method of Vargas and co-workers ${ }^{19}$. A stock concentration $(25 \mathrm{mg} / \mathrm{mL})$ of the plant extract/standard antimalarial drug (chloroquine) was prepared in aliquot of DMSO and subsequently diluted in solution containing 0.1 $\mathrm{M} \mathrm{HCl}$, methanol and DMSO in the following ratio 5:3:1 to give 12.5 $\mathrm{mg} / \mathrm{mL}$ working solution. The final concentration after addition of various reagents in the test plate (24-well plate) resulted in $0.69 \mathrm{mg} / \mathrm{mL}$. Briefly, $10 \mu \mathrm{L}$ of plant extract 1, 2 and chloroquine were dispensed into different wells in column 1 - 6 in duplicates. In this format two extracts and a standard drug (chloroquine) were tested in the 24-well plates. In addition, $10 \mu \mathrm{L}$ of $1 \mathrm{M} \mathrm{HCl}$ was added to all plant extracts or chloroquine in the 24-well plates. Into the wells in row A and B (the first two rows) $100 \mu \mathrm{L}$ of freshly prepared hematin solution was added while wells in row $\mathrm{C}$ and $\mathrm{D}$ received $100 \mu \mathrm{L}$ of $0.1 \mathrm{M} \mathrm{NaOH}$. The test plate was shaken at $450 \mathrm{rpm}$ for $10 \mathrm{~min}$. This was followed by addition of $60 \mu \mathrm{L}$ of saturated acetate solution, pre-warmed at $60^{\circ} \mathrm{C}$ into all the wells. The test plate was further incubated at $60^{\circ} \mathrm{C}$ for $90 \mathrm{~min}$. Thereafter, $750 \mu \mathrm{L}$ of $15 \%$ pyridine was added to wells in the first and the third rows (row A and C) while $750 \mu \mathrm{L}$ HEPES ( $\mathrm{pH} 7.5$ ) was added to wells in the second and the fourth rows (row B and D). Furthermore, the test plate was shaken at $450 \mathrm{rpm}$ for $10 \mathrm{~min}$ and allowed to settle for $15 \mathrm{~min}$. An aliquot of $100 \mu \mathrm{L}$ was transferred in duplicates to a new 96-well plate and absorbance read at $405 \mathrm{~nm}$ with a spectrophotometer (SPECTRAmax GEMINI XS, Molecular Devices, USA).

Following the initial screening, methanol extract of 6 most active medicinal plants were quantitatively tested on the $\beta$-hematin assay at concentrations ranging from 0.04 to $1.38 \mathrm{mg} / \mathrm{mL}$. The plant extract/drug concentrations were plotted against $\mathrm{I}_{\text {Analysis }}$. The $\mathrm{IC}_{50}$ of the plant extract/standard drug was determined using a linear regression in a commercially available statistical package Microcal Origin ${ }^{\circledR}$.

\section{Data Analysis}

For each plant extract/drug tested, (the absorbance, represented as $\mathrm{A}_{\text {Analysis }}$ ) there was a control analysis $\left(\mathrm{A}_{\text {Analysis }} ;{ }_{\text {Blank }}\right)$, which differed from the plant extract/drug submitted for the analysis $\left(\mathrm{A}_{\text {Analysis }}\right)$ by the addition of $750 \mu \mathrm{L}$ of $20 \mathrm{mM}$ HEPES instead of pyridine, after incubation. In addition, for each plant extract/drug, a blank control $\left(\mathrm{A}_{\text {CLT; Blank }}\right)$ as well as its blank $\left(\mathrm{A}_{\text {CLTBlank; Blank }}\right)$ were prepared in the absence of hematin but with $750 \mu \mathrm{L}$ of $15 \%$ pyridine or $750 \mu \mathrm{L}$ of HEPES.

1. Absorbance of the complex due to the remaining hematin in wells was calculated using the following formula: 
Change in absorbance $\left(\Delta \mathrm{A}_{\text {Analysis }}\right)=\mathrm{A}_{\text {Analysis }}-\mathrm{A}_{\text {Analysis; Blank }}$

2.The residual absorbance $\left(\Delta \mathrm{A}_{\text {CLT; Blank }}\right)$ of the plant extract/drug independent from the inhibition of the $\beta$-hematin complex was calculated using the following formula:

$\Delta_{\text {ACLT; Blank }}=\mathrm{A}_{\text {CLTBlank }}-\mathrm{A}_{\text {CLTBlank; Blank }}$

3. The resulting inhibition of the $\beta$-hematin synthesis induced by the plant extract/drug was calculated using the following formula:

$\mathrm{I}_{\text {Analysis }}=\Delta \mathrm{A}_{\text {Analysis }}{ }^{-}{ }_{\Delta \mathrm{ACLT} ; \text { Blank }}$

A positive $\mathrm{I}_{\text {Analysis }}$ is considered as positive (active sample) whereas a negative value indicated a negative result ${ }^{47}$.The $\mathrm{IC}_{50}$ values were means \pm standard deviation of three independent experiments. Mann-Whitney $U$ test was used to compare the mean IC50 of the plant extracts with that of chloroquine. P-value $<0.05$ was considered significant.

\section{RESULTS}

The $\mathrm{I}_{\text {Analysis }}$ values of methanol extracts of the 20 medicinal plants at a fixed concentration of $0.69 \mathrm{mg} / \mathrm{mL}$ varied and ranged from -0.002 to 0.39 (Table 1). At this fixed concentration, nineteen (19) out of the 20 methanol extracts showed positive $\mathrm{I}_{\text {Analysis }}$ values. Only methanol extract of leaf of Ocimum gratissimum showed negative $I_{\text {Analysis }}$ value (-0.002) signifying inability to inhibit the formation of $\beta$-hematin). Methanol extract of Alstonia boonei stem bark displayed the highest $\mathrm{I}_{\text {Analysis }}$ value of 0.39 while methanol extract of Sida acuta displayed the lowest IAnalysis value of 0.06 at a fixed concentration of $0.69 \mathrm{mg} / \mathrm{mL}$. In addition, the $\mathrm{I}_{\text {Analysis }}$ value of the standard drug chloroquine was 0.17 (Table 1).
Table 1. Percentage Yield and Beta-Hematin Inhibition of Twenty Selected Medicinal Plant Extracts

\begin{tabular}{|c|c|c|c|c|}
\hline $\mathrm{S} / \mathrm{N}$ & Plants/Drug & Family & $\begin{array}{c}\text { Percentage } \\
\text { Yield (\%) }\end{array}$ & $\begin{array}{l}I_{\text {analysis }}(0.69 \mathrm{mg} / \\
\mathrm{mL})\end{array}$ \\
\hline 1. & Morinda lucida & Rubiaceae & 23.0 & 0.11 \\
\hline 2. & Terminalia catappa & Combretaceae & 9.2 & 0.18 \\
\hline 3. & Ocimum gratissimum & Lamiaceae & 7.0 & -0.002 \\
\hline 4. & Cajanus cajan & Fabaceae & 9.6 & 0.15 \\
\hline 5. & Vitex doniana & Lamiaceae & 6.4 & 0.13 \\
\hline 6. & Gossypium barbandense & Malvaceae & 7.3 & 0.17 \\
\hline 7. & Azadirachta indica & Meliaceae & 12.2 & 0.12 \\
\hline 8. & Mangifera indica & Anacardiaceae & 13.1 & 0.21 \\
\hline 9. & Phyllantus amarus & Phyllanthaceae & 6.3 & 0.24 \\
\hline 10. & Senna siamea & Fabaceae & 10.1 & 0.09 \\
\hline 11. & Lawsonia inermis & Lythraceae & 22.2 & 0.26 \\
\hline 12. & Nicotiana tabacum & Solanaceae & 18.6 & 0.21 \\
\hline 13. & Xylopia aethiopica & Annonaceae & 28.7 & 0.10 \\
\hline 14. & Allium sativum & Amaryllidaceae & 3.0 & 0.10 \\
\hline 15. & Euphorbia hirta & Euphorbiaceae & 11.7 & 0.07 \\
\hline 16. & Vernonia amygdalina & Asteraceae & 15.9 & 0.12 \\
\hline 17. & Momordica charantia & Cucurbitaceae & 9.2 & 0.26 \\
\hline 18. & Cymbopogon citratus & Poaceae & 3.2 & 0.19 \\
\hline 19. & Sida acuta & Malvaceae & 9.8 & 0.06 \\
\hline 20. & Alstonia boonei* & Apocynaceae & 5.2 & 0.39 \\
\hline 21. & Chloroquine+ & NA & NA & 0.17 \\
\hline
\end{tabular}

* With the exception of Alstonia boonei where the stem bark extract was tested, the methanol extract of leaves of the other medicinal plants were evaluated, ${ }^{+}$Standard antimalarial drug, NA - not applicable.

In addition, the $50 \%$ inhibitory concentration $\left(\mathrm{IC}_{50}\right)$ of the 6 most active medicinal plants from the initial screening was $\left(\mathrm{I}_{\text {Analysis }} \geq 0.21\right)$ quantitatively tested on the $\beta$-hematin assay at concentrations ranging from 0.04 to $1.38 \mathrm{mg} / \mathrm{mL}$. Of the six methanol extracts tested, five possessed higher inhibitory activity greater than the standard drug chloroquine. Methanol extract of Alstonia boonei was the most ac- 
tive with $\mathrm{IC}_{50}$ value of $0.09 \pm 0.03 \mathrm{mg} / \mathrm{mL}$ while the extract of Nicotiana tabacum was the least active with $\mathrm{IC}_{50}$ value of $0.49 \pm 0.05 \mathrm{mg} / \mathrm{mL}$ (Table 2). The mean $\mathrm{IC}_{50}$ value of chloroquine a potent $\beta$-hematin inhibitor was $0.36 \pm 0.16 \mathrm{mg} / \mathrm{mL}$ (Table 2).

Table 2. Fifty Percent Inhibitory Concentration $\left(\mathrm{IC}_{50}\right)$ of Ten Medicinal Plants in a BetaHaematin Inhibition Assay

\begin{tabular}{|c|c|c|}
\hline $\mathrm{S} / \mathrm{N}$ & Plant Extracts/Drug & $\begin{array}{c}I_{50}\left(\begin{array}{c}\text { Mean } \\
(\mathrm{mg} / \mathrm{mL})\end{array}\right. \\
\text { S.D })\end{array}$ \\
\hline 1 & Alstonia boonei & $0.09 \pm 0.03^{*}$ \\
\hline 2 & Momordica charantia & $0.11 \pm 0.02^{*}$ \\
\hline 3 & Phyllantus amarus & $0.19 \pm 0.03$ \\
\hline 4 & Lawsonia inermis & $0.24 \pm 0.05$ \\
\hline 5 & Mangifera indica & $0.25 \pm 0.07$ \\
\hline \multirow[t]{2}{*}{6} & Nicotiana tabacum & $0.49 \pm 0.05$ \\
\hline & Chloroquine & $0.36 \pm 0.16$ \\
\hline
\end{tabular}

$\mathrm{N}=3,{ }^{*}$ Chloroquine vs Alstonia boonei and Momordica charantia $\mathrm{P}<0.05$

\section{DISCUSSION}

Host haemoglobin is an essential source of amino acids for parasite growth ${ }^{20,21}$ for intraerthrocytic stages of malaria parasite i.e. rings, trophozoites and schizonts ${ }^{20-22}$. The food vacuole of the parasites contains specialised aspartic and cysteine proteases. These enzymes degrade the protein component of haemoglobin to amino acids, which are utilised by the parasite for protein synthesis ${ }^{23-24}$. The remaining part of the degraded haemoglobin is the haem (ferriprotoporphyrin IX), which is released intact. The haem produced along with amino acids after degradation of host haemoglobin is toxic to the parasites. Haem is membrane toxic, capable of lysing both the parasites and the red blood cells ${ }^{25}$. The parasites detoxified haem by converting it to an insoluble, unreactive crystalline material called haemozoin (malaria pigment) or $\beta$-haematin ${ }^{26}$.Inhibition of conversion of toxic haem to $\beta$-haematin by 4 -aminoquinolines or the complex formed by toxic haem and some antimalarial drugs would effectively allow the build-up of haem to a level that become irreversibly toxic to the parasite. Thus, the haemozoin formation pathway has been widely studied and explored as the mechanistic pathway for the 4-aminoquinolines antimalarial drugs such as chloroquine, mefloquine and amodiaquine13-15. This pathway is also considered a suitable target for antimalarial drug discovery ${ }^{27-29}$.

The $\beta$-haematin formation pathway was explored in this study to evaluate the mechanism of antimalarial activity of twenty medicinal plant species from six- teen different families reputed to be of importance in ethnomedicine for the treatment of malaria. Nineteen out of the twenty plant extracts showed positive $\mathrm{I}_{\text {Analysis }}$ values which signified activity against $\beta$-hematin synthesis. Two of the plant extracts (A. boonei and $M$. charantia), showed significant activity than chloroquine $(\mathrm{P}<0.05)$. Others active plant extracts were $P$. amarus, $L$. inermis, $M$. indica and $N$. tabacum. These plants showed higher inhibition of $\beta$-hematin synthesis than chloroquine a known $\beta$-hematin synthesis inhibitor. The previously reported antimalarial activity of $A$. boonei ${ }^{30}, M$. charantia ${ }^{31-33} P$. amarus $^{34}$, L. inermis $^{30}$, and $M$. indica ${ }^{35}$ in a parasite based assay using in vitro $P$. falciparum might due to inhibition of $\beta$-hematin synthesis in the parasites. It appears there is no information on antimalarial activity of $N$. tabacum. However, larvicidal, mosquitocidal and antioxidant activities of $N$. tabacom were previously reported ${ }^{36-37}$ The mechanism of antimalarial activity of these plant species from sixteen different families vis-avis inhibition of $\beta$-hematin synthesis is being reported for the first time.

\section{CONCLUSION}

The $\beta$-hematin colorimetric assay is a reliable assay for determining the mechanism of action of antimalarial agents that utilize the pathway.

Both authors reviewed and approved of the final manuscript.

\section{ACKNOWLEDGEMENT}

The authors are grateful to Dr. Sergio Wittlin of Swiss Tropical and Public Health Institute, Basel, Switzerland for provision of some of the reagents for the experiment.

\section{CONFLICT OF INTEREST}

We declare no conflict of interest.

\section{REFERENCES}

1. WHO.. Fact Sheet: Malaria. 2016. http://www.who.int/mediacentre/factsheets/fso94/en/ 2. WHO. Fact Sheet: World Malaria Report. 2015. http://www.who.int/malaria/media/worldmalaria-report-2015/en/

3. Noedl, H.; Se, Y.; Schaecher, K.; Smith, B.L.; Socheat, D.; Fukuda, M.M. Evidence of artemisinin-resistant malaria in western Cambodia. Artemisinin Resistance in Cambodia 1 (ARC1) Study Consortium. N Engl J Med. 2008, 359(24), 2619-20.

4. Dondorp, A.; Nosten, F.; Yi, P.; Das, D.; Phyo, A.P.; Tarning, J.; Lwin, K.M.; Ariey, F. Hanpithakpong, W.; Lee, S.J.; Ringwald, P.; Silamut, K.; Imwong, M.; Chotivanich, K.; Lim, P.; Herdman, T.; An, S.S.; Yeung, S.; Singhasivanon, P.; Day, N. P.; Lindegardh, N.; Socheat. D.; White, N. J. . Artemisinin resistance in Plasmodium falciparum malaria. N Engl J Med. 2oog, 361(5), 455-67.

5. Dondorp, A.M.; Fairhurst, R.M.; Slutsker, L.; Macarthur, J.R.; Breman, J.G.; Guerin, P.J.; 
Wellems, T.E.; Ringwald, P.; Newman, D.; Plowe, C.V. The threat of artemisinin-resistant malaria. N Engl J Med. 2011, 365(12), 1073-5.

6. Surolia, N.; Padmanaban, G.G. de novo biosynthesis of heme offers a new chemotherapeutic target in the human malarial parasite. Biochem Biophys Res Commun. 1992, 187(2),744-50.

7. Subbayya, I.N.; Ray, S.S.; Balaram, P.; Balaram, H. Metabolic enzymes as potential drug targets in Plasmodium falciparum. Indian J Med Res. 1997, 106, 79-94.

8. Egan, T.J.; Haemozoin (malaria pigment): a unique crystalline drug target. Targets. $\mathbf{2 0 0 3 ,}$ $115-124$.

9. Mitra, P.; Deshmukh, A.S.; Dhar, S.K. DNA replication during intra-erythrocytic stages of human malarial parasite Plasmodium falciparum. Curr Sci. 2012, 102, 725-740.

10. Ridley, R.G. Medical need, scientific opportunity and the drive for antimalarial drugs. Nature. 2002, 415(6872), 686-693.

11. Pagola, S.; Stephens, P.W.; Bohle, D.S.; Kosar, A.D.; Madsen, S.K. The structure of malaria pigment $\beta$-haematin. Nature. 20oo, 404(6775), 307-310.

12. Soares, J.B.C.; Menezes, D.; Vannier-Santos, M.A.; Ferreira-Pereira, A.; Almeida, G.T.; Venancio, T.M.; Verjovski-Almeida, S.; Zishiri, V. K.; Kuter, D.; Hunter, R.; Egan, T.J. Interference with hemozoin formation represents an important mechanism of schistosomicidal action of antimalarial quinoline methanols. PLoS Negl Trop. Dis. 2oog, 3(7), e477.

13. Egan, T.J.; Ross, D.C.; Adams, P.A. Quinoline anti-malarial drugs inhibit spontaneous formation of beta-haematin (malaria pigment). FEBS. Lett. 1994, 352(1), 54-57.

14. Egan, T.J. Haemozoin formation. Mol Biochem Parasitol. 20o8, 157, 127-136.

15. de Villiers, K.A.; Egan, T.J. Recent advances in the discovery of haem-targeting drugs for malaria and schistosomiasis. Molecules 2009, 14(8), 2868-2887.

16. Sullivan, D.J. Theories on malarial pigment formation and quinoline action. Int. J. Parasitol. 2002, 32(13), 1645-1653.

17. Eastman, R.T.; Fidock, D.A. Artemisinin-based combination therapies: A vital tool in efforts to eliminate malaria. Nat Rev Microbiol. 2009, 7(12), 864-874.

18. Haynes, R.K.; Cheu, K.W.; Li, K.Y.; Tang, M.M.K.; Wong, H.N.; Chen, M.J.; Guo, Z.F.; Guo, Z.H.; Coghi, P., and Monti, D. 2A partial convergence in action of methylene blue and artemisinins: antagonism with chloroquine, a reversal with verapamil, and an insight into the antimalarial activity of chloroquine. Chem Med Chem. 2oo1, 6(9), 1603-1615.

19. Vargas, S.; Ioset, K.N.; Hay, A.E.; Ioset, J.R.; Wittlin, S.; Hostettmann, K. Screening medicinal plants for the detection of novel antimalarial products applying the inhibition of $\beta$-hematin formation. J Pharm Biomed Anal. 2o11, 56(5), 880-886.

20. Rosenthal, P.J.; Meshnick, S.R. Hemoglobin processing and the metabolism of amino acids, heme \& iron. In: Malaria; Parasite Biology, Pathogenesis \& Protection. I.W. Sherman ed. ASM press, Washington D.C.P. 1998, 145-158.

21. Banerjee, R.; Goldberg, D.E. The Plasmodium food vacuole. In: Antimalarial chemotherapy. P.J. Rosenthal, ed. Human Press, Totowa, NJ.P. 2001, 43-63.

22. Egan, T.J; Ross, D.C.; Adams, P.A. The mechanism of action of quinolines and related antimalarial drugs. S Afr J Sci. 1996, 92, 11-14.

23. Banerjee, R.; Lin, J.; Beatty, W.; Pelosof, L.; Klembe, M.; Goldberg, D.E. Four plasmepsins areactive in the Plasmodium falciparum food vacuole, including a protease in an active site histidine. Proc Natl Acad Sci. 2002, 99, 995.
24. Goldberg, D.E.; Slater, A.F.G.; Beavis, R.; Chait, B.; Cerami, A. Hemoglobin degradation in human malaria pathogen Plasmodium falciparum: a catabolic pathway initiated by a specific aspartic protease. J Exp Med. 1991, 173(4), 961-9.

25. Fitch, C.D.; Chevli, R.; Bayal, A.S.; Philips, G.; Pfaller, M.A.; Krogstad, D.J. Lysis P. falciparum by ferriprotoporphyrin IX \& a CQ - ferriprotoporphyrin IX complex. Antimicrob Agents Chemother. 1982, 21, 819-82.

26. Slater, A.F.G.; Cerami, A. Inhibition of chloroquine of a novel haem polymerase enzyme activity in malaria trophozoites. Nature, 1992, 355, 167-169

27. Dorn, A.; Vippagunta, S.R.; Matile, H.; Jaquet, C.; Vennerstrom, J. L.; Ridley, R.G. An assessment of drug-haematin binding as a mechanism for inhibition of haematin polymerisation by quinoline antimalarial. Biochem Pharm. 1998, 55, s727-736.

28. Egan, T.J. Haemozoin (malaria pigment): a unique crystalline drug target. Targets. 2003, $115^{-124}$

29. Sullivan, D.; Gluzman, I.Y.; Russell, D.G.; Goldberg, D.E. On the molecular mechanism of chloroquine's antimalarial action. Proc Natl Acad Sci. 1996, 93, 11865-11870.

30. Okpekon, T.; Yolou, S.; Gleye, C.; Roblot, F.; Loiseau, P.; Bories, C.; Grellier, P.; Frappier, F.; Laurens, A.; Hocquemiller, R. Antiparasitic activities of medicinal plants used in Ivory Coast. J Ethnopharmacol. 2004, 90(1), 91-7.

31. Kamaraj, C.; Kaushik, N.K.; Rahuman, A.A.; Mohanakrishnan, D.; Bagavan, A.; Elango, G.; Zahir, A.A.; Santhoshkumar, T.; Marimuthu, S.; Jayaseelan, C.; Kirthi, A.V.; Rajakumar, G.; Velayutham, K.: Sahal, D. Antimalarial activities of medicinal plants traditionally used in the villages of Dharmapuri regions of South India. J Ethnopharmacol. 2012, 141(3),796-802.

32. Olasehinde, G.I.; Ojurongbe, O.; Adeyeba, A.O.; Fagade, O.E.; Valecha, N.; Ayanda, I.O.; Ajavi, A.A.; Eswari, L.O. In vitro studies on the sensitivity pattern of Plasmodium falciparum to anti-malarial drugs and local herbal extracts. Malar J. 2014, 20, $13,63$.

33. Amorim, C.Z.; Marques, A.D.; Cordeiro, R.S. Screening of the antimalarial activity of plants of the Cucurbitaceae family. Mem Inst Oswaldo Cruz. 1991, 86, Suppl 2, 177-80.

34. Abiodun, O.; Gbotosho, G.; Ajaiyeoba, E.; Happi, T.; Falade, M.; Wittlin, S.; Sowunmi, A.; Brun, R.; Oduola, A. In vitro antiplasmodial activity and toxicity assessment of some plants from Nigerian ethnomedicine. Pharm Biol. 2011, 49(1), 9-14.

35. Arrey, T. P.; Franzoi, K. D.; Lee, S.; Lee, E.; Vivarelli, D.; Freitas-Junior, L.; Liuzzi, M.; Nolé, T.; Ayong, L.S.; Agbor, G.A.; Okalebo, F.A.; Guantai, A.N. In vitro antiplasmodial activities and synergistic combinations of differential solvent extracts of the polyherbal product, Nefang. Biomed Res Int. 2014, 2014(835013).

36. Ileke, K.D.; Oyeniyi, E.A.; Ogungbite, O.C.; Adesina, J. M. Nicotianatabacum a prospective mosquitocide in the management of Anopheles gambiae (Giles). International J Mosquito Res. 2015, 2(4), 19-23.

37. Gratão, P. L.; Pompeu, G.B.; Capaldi, F.R.; Vitorello, V.A.; Lea, P.J. Azevedo RA. Antioxidant response of Nicotiana tabacum cv. Bright Yellow 2 cells to cadmium and nickel stress. Plant Cell Tiss Organ Cult 2008, 94(1), 73-83. 